\title{
Localized beach contamination in American Samoa: Results from two years of weekly monitoring
}

\author{
Guy T. DiDonato *, Elena B. Paselio \\ American Samoa Environmental Protection Agency, P.O. Box PPA, Pago Pago 96799, American Samoa
}

American Samoa, an archipelago of five volcanic islands and two coral atolls, lies at approximately $14^{\circ} \mathrm{S}$ and $170^{\circ} \mathrm{W}$. Of the American Samoan Islands, Tutuila is both the largest and the locus of government and commerce. This $53-\mathrm{mi}^{2}$ island is also where over $96 \%$ of the current population resides (57,291 out of 58,706 as of the 2000 Census; American Samoa Government, 2002). That population is concentrated on the southern side of Tutuila, particularly in the Pago Pago Harbor region. Pago Pago Harbor has a history of environmental degradation. Nutrient enrichment from a local tuna canning facility, excessive sedimentation from poor land use decisions, and widespread reef flat modification (Cornish and DiDonato, 2004) have all contributed to periods of poor water quality and largescale loss of coral reef communities in the harbor and its proximity.

Pago Pago Harbor has a high concentration of people and local commerce, and the beaches in that region are used frequently by both residents and visitors. Consequently, there is an emerging need to monitor those bathing water for potential bacterial contamination and associated health risks (Henrickson et al., 2001). The American Samoa Environmental Protection Agency (ASEPA) monitors bacterial contamination at many territorial beaches, but that effort is concentrated in Pago Pago Harbor and its close proximity. This report details the results of weekly beach monitoring done during the twoyear period beginning in 2002.

During 2002, 14 beaches were included as part of regular weekly monitoring. One beach, Aua Stream Beach, was added after the first 8 weeks of 2002. These same 14 sites were continued through 2003, and two additional beach sites (Alega Beach and Alega Stream) were added to the weekly sampling schedule beginning in March, 2003. The location of all sampled beaches is shown in Fig. 1.

Beach sampling was conducted on Tuesday mornings. At each site, approximately 0.51 water was collected in a sterile bottle in water depth no less than knee level of the collector, independent of tidal height. While tidal stage can be an important determinant of bacterial contamination (Mallin et al., 1999), no effort was made in either field collection or data analysis to remove the potential variabil-

\footnotetext{
${ }^{*}$ Corresponding author. Present address: Hollings Marine Laboratory, 331 Fort Johnson Road, Charleston, SC 29412, USA. Tel.: +1 843762 8932; fax: +1 8437628737.

E-mail address: didonato_guy@hotmail.com (G.T. DiDonato).
}

ity introduced by the tidal dynamic. Collected samples were stored in coolers and returned to the laboratory within $2 \mathrm{~h}$. Enterococci, the selected indicator bacteria, were enumerated using Enterolert ${ }^{\circledR}$ and most probable number (MPN) methods. Enterolert ${ }^{\circledR}$ utilizes chromogenic substrate technology to enumerate bacteria and compares favorably with estimates using traditional methods (i.e., membrane filtration or multiple tube fermentation; Noble et al., 2003). Enterococci numbers were compared to the American Samoa Water Quality Standards (ASWQS) to determine beach compliance. The ASWQS specify a single-sample maximum bacteria number (per $100 \mathrm{ml}$ ) to be 124 for open coastal habitats and 104 for special embayments, including Pago Pago Harbor. If a site exceeded this single-sample limit, it violated the standard and was considered contaminated. To summarize these data, the number of contaminated sites was tallied each week. Furthermore, the amount of time (expressed as a percentage of weeks for each annual period) that each site exceeded the ASWQS was calculated.

During monitoring, it was observed that the number of contaminated sites was higher when samples were collected during or just after periods of heavy rainfall. To investigate the relationship between beach contamination and precipitation, we utilized daily rainfall summary data compiled by the National Weather Service Office (NWSO) at Pago Pago International Airport (Fig. 1). Tutuila receives between 125 and 250 inches of rain per year. Higher rainfall $(2 x)$ generally occurs in the harbor region (the location of about half of these beach sites) compared to the airport; however, data from the NWSO were the only data available for the entire two-year period of study. Prior to analyses, enterococci counts (MPN) were $\log (x+1)$-transformed, and rainfall data (inches of rain on each Tuesday) were $-1 /(x+1)^{3}$-transformed. Correlations between rainfall and site-specific bacterial contamination levels were evaluated with Pearson's product-moment correlations. In addition, since a few of the distributions were not normalized by transformation, we conducted Pearson's correlation analyses on rank-transformed data. This is the equivalent of a nonparametric correlation analysis and was used only to evaluate the parametric test results. The two sites added later in 2003 (Alega Beach and Alega Stream) were not included in correlation analyses.

In 2002, up to 14 sites exceeded the ASWQS standard each week (Fig. 2), and the median number of sites was 3 (of 14 , or $21 \%$ ). Of the 16 sites sampled in 2003 , up to 15 


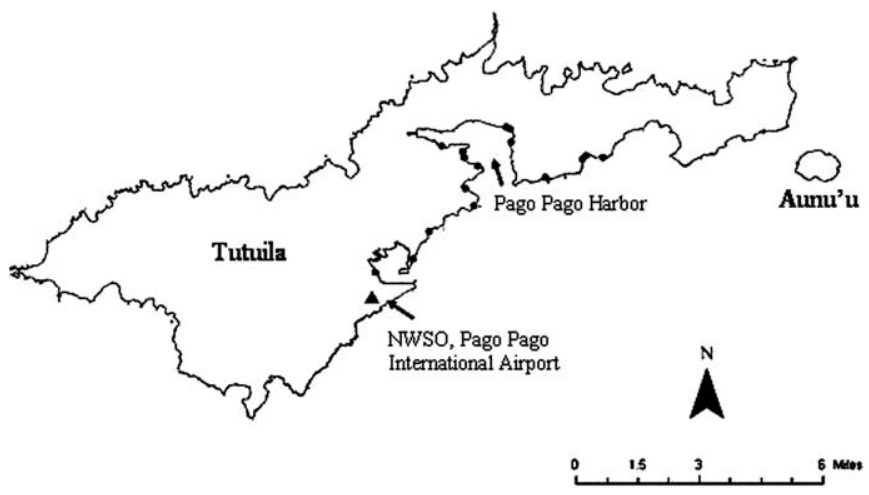

Fig. 1. An outline map of Tutuila (American Samoa) showing the sampling locations for weekly beach monitoring. Site names, from west to east beginning closest to the National Weather Service Office (NWSO) are: Pala Lagoon, Coconut Point, Avau, Fatumafuti, Fagaalu, Gataivai, Yacht Club, Utulei Beach, Fagatogo, Pouesi-Aua, Aua Stream, DiosaAua, Laulii, Alega Beach, Alega Stream, and \$2 Beach.

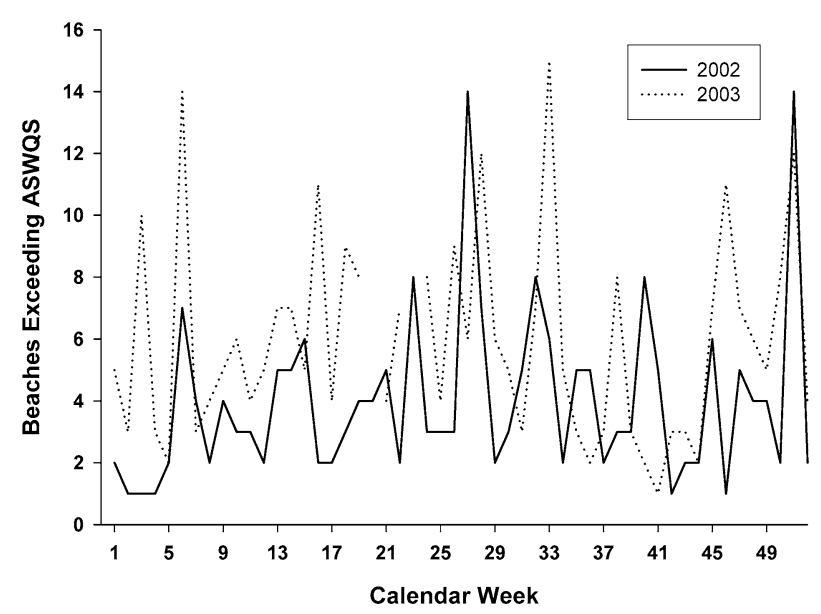

Fig. 2. Number of local beaches each week that demonstrated a singlesample violation of the American Samoa Water Quality Standards (ASWQS) during the monitoring period 2002-2003.

violated the single-sample standard each week (Fig. 2), while the median number was 5 (of 16 , or $31 \%$ ). Sites that often exceeded the standard were consistent across the twoyear monitoring period (Fig. 3). Five sites (Fagatogo, Pouesi-Aua, Aua Stream, Diosa-Aua, and Laulii) exceeded the standard between $35 \%$ and $96 \%$ of the time in 2002, and those same sites were positive between $50 \%$ and $98 \%$ of the sampled weeks in 2003. The sites added in 2003 (Alega Beach, Alega Stream) also frequently exceeded the beach standard (30\% and $68 \%$, respectively). It is important to note, however, that the increase from three to five sites out of compliance with the standard between the study years was not simply a result of adding two more sites in the second year. Instead, site-specific increases in the violation frequency (e.g., Fagaalu, Coconut Point; Fig. 3) caused the overall increase in the number of beaches violating the ASWQS. Perhaps an important indication of water quality trends in American Samoa is that none of the beach sites decreased in frequency of violations between 2002 and 2003 (Fig. 3).

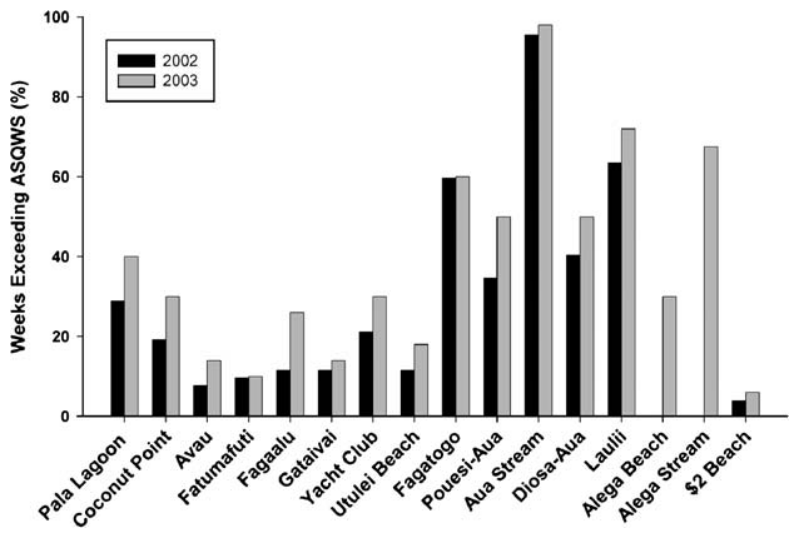

Fig. 3. The percentage of weeks both in 2002 and 2003 that each monitored beach violated the bacterial standard. Alega Beach and Alega Stream were not sampled in 2002.

When compared to the water quality standards for American Samoa, these data demonstrate persistent and widespread beach contamination for sites on Tutuila's south shore. The mere presence of enterococci in beach water, however, does not necessarily always indicate human-related contamination. In tropical environments, these bacteria persist in the soils and are transported via stream flow to the beach areas (Luther and Fujioka, 2004). On Tutuila, the three sites that exceeded the bacterial water quality standard most often during 2003 (Aua Stream (98\%), Laulii (72\%), and Alega Stream (68\%)) are each close to mouths of large streams. Fagatogo also had a high frequency of violations $(60 \%)$ and is similarly close to a stream mouth. Proximity to a stream discharge in these cases may influence localized contamination.

However, proximity to a stream and naturally occurring bacteria populations is likely not the only explanation for the observed contamination. There are many other potential sources of contamination in American Samoa, including contaminated storm runoff, leachate from cesspools and faulty or improperly constructed septic tanks, and direct discharge of wash-down water from small-scale familyowned pig sties. The impacts of these sources are exacerbated by the patterns of development on the island. Most of the residential development on Tutuila has occurred in the narrow strip of generally level coastal land, and the increase in impervious surfaces associated with development has increased the amount of surface water runoff discharged directly into the nearshore habitats. Noble et al. (2000) found that storm drains and consolidated runoff were the causes of most violations of California's water quality standards for nearshore waters. Improper waste loads from management and/or disposal of human waste in coastal villages is likely an important contributor to nearshore bacterial contamination as well. The municipal sewer system currently serves approximately $40 \%$ of Tutuila's population, and most households rely on cesspools and improperly constructed septic systems for wastewater management. Potential contamination also comes from 
Table 1

Pearson's product-moment correlation coefficients between Enterococcus counts (MPN) and rainfall

\begin{tabular}{ll}
\hline Site & Pearson's coefficient \\
\hline Pala Lagoon & $0.203^{*}$ \\
Coconut Point & $0.125 \mathrm{~ns}$ \\
Avau & $0.221^{*}$ \\
Fatumafuti & $0.327^{* *}$ \\
Fagaalu & $0.396^{* *}$ \\
Gataivai & $0.260^{* *}$ \\
Yacht Club & $0.372^{* *}$ \\
Utulei Beach & $0.341^{* *}$ \\
Fagatogo & $0.251^{*}$ \\
Pouesi-Aua & $0.256^{*}$ \\
Aua Stream & $0.124 \mathrm{~ns}$ \\
Diosa-Aua & $0.317^{* *}$ \\
Laulii & $0.182 \mathrm{~ns}$ \\
\$2 Beach & $0.057 \mathrm{~ns}$ \\
\hline
\end{tabular}

$\mathrm{ns}=$ not significant.

${ }^{*} p<0.05$.

** $0.001<p<0.01$

*** $p<0.001$.

the mismanagement of waste from family-owned pig sties ("piggeries"). Most piggeries are located immediately adjacent to stream banks or the ocean shoreline, and owners simply wash pig waste directly into water bodies.

Local rainfall also appears to influence nearshore contamination. Correlation analyses demonstrated significant relationships between rainfall and enterococci counts at 10 of the 14 sites $(71 \%$; see Table 1$)$. Significant correlation coefficients ranged from 0.203 to 0.396 , so the overall amount of variability explained by the correlation was low ( $R^{2}$ between $4.1 \%$ and $15.7 \%$ ). The correlation analysis with rank-transformed data generally confirmed the parametric test results, showing that rainfall and enterococci were positively correlated at 8 of the 14 sites. (Neither Pala Lagoon nor Fatumafuti showed significant correlations when using the ranked data.) In comparison, the Commonwealth of the Northern Mariana Islands (CNMI) Department of Environmental Quality reported that 53.8\% of Saipan's west beaches sampled weekly showed a significant correlation between rainfall and bacterial contamination (CNMI, 2004).

The correlation between rainfall and contamination suggests that rainfall moves contaminants from the land, either through the stream conduit or via overland runoff and storm drains. In some cases it seems to be associated primarily with stream transport. Several sites located near a stream (e.g., Yacht Club, Utulei Beach) showed increased levels of contamination with increased rainfall, and the increased stream discharge during the tropical rains may contaminate those sites. The bathing beaches on either side of the Aua Stream site (Pouesi-Aua and Diosa-Aua) violate the ASWQS between $40 \%$ and $50 \%$ of the time, and bacterial counts at those sites are correlated with rainfall
(Table 1). This implies that, after periods of rain when discharge is high, the contamination coming from Aua Stream can influence sites on either side of the stream mouth. On the contrary, some beaches are not adjacent to a stream discharge and still show a positive correlation between rainfall and contamination. Gataivai, for example, is far from any stream inputs, and in this case overland flow and storm drains may contribute a significant proportion of the contamination during rainy periods.

In conclusion, these data strongly suggest that Tutuila's nearshore waters face persistent contamination problems, and these data can serve as a baseline as efforts are turned now, where possible, towards addressing these problems.

\section{Acknowledgements}

Preliminary work to establish the ASEPA beach monitoring program under the US Beaches Environmental Assessment and Coastal Health Act funding was spearheaded by one of the authors (EBP) and E. Buchan of the ASEPA Water Program. Other people that contributed to the foundation of this work were C. Goldstein (USEPA) and J. Craig (ASEPA). K. Cronk (ASDOC) collected spatial data and provided mapping assistance. ASEPA laboratory staff (J. Kim, F. Logologo, J. Masaniai, A. Tago, and I. Vaouli) collected beach samples and conducted all laboratory analyses. P. Peshut (ASEPA) and one anonymous reviewer provided helpful editorial comments.

\section{References}

American Samoa Government, 2002. American Samoa Statistical Yearbook 2000. Statistics Division, Department of Commerce, Pago Pago, American Samoa, 188p.

CNMI (Commonwealth of Northern Mariana Islands), 2004. Integrated 305(b) and 303(d) Water Quality and Assessment Report. Division of Environmental Quality, Saipan, 60p.

Cornish, A.S., DiDonato, E.M., 2004. Resurvey of a reef flat in American Samoa after 85 years reveals devastation to a soft coral (Alcyonacea) community. Marine Pollution Bulletin 48, 768-777.

Henrickson, S.E., Wong, T., Allen, P., Ford, T., Epstein, P.R., 2001. Marine swimming-related illness: implications for monitoring and environmental policy. Environmental Health Perspectives 109, 645659.

Luther, K., Fujioka, R., 2004. Usefulness of monitoring tropical streams for male-specific RNA coliphages. Journal of Water and Health 2, 171-181.

Mallin, M.A., Esham, E.C., Williams, K.E., Nearhoof, J.E., 1999. Tidal stage variability of fecal coliform and chlorophyll $a$ concentrations in coastal creeks. Marine Pollution Bulletin 38, 414-422.

Noble, R.T., Dorsey, J.H., Leecaster, M., Orozxo-Borbon, V., Reid, D., Schiff, K., Weisberg, S.B., 2000. A regional survey of the microbiological water quality along the shoreline of the Southern California Bight. Environmental Monitoring and Assessment 64, 435-447.

Noble, R.T., Weisberg, S.B., Leecaster, M.K., McGee, C.D., Ritter, K., Walker, K.O., Vainik, P.M., 2003. Comparison of beach bacterial water quality indicator measurement methods. Environmental Monitoring and Assessment 81, 301-312. 